\title{
Efek Domino Gerakan Tiga Daerah di Bantaeng 1999-2014
}

\author{
Ulil Amri, Ahmadin, Jumadi \\ Pendidikan Sejarah FIS UNM \\ Ulilamri071@gmail.com
}

\begin{abstract}
Abstrak
Tulisan ini membahas mengenai Pergerakan Kaloling, Layoa, Bajiminasa di Bantaeng 19992014. Adapun tujan penelitian akan diarahkan latar belakang pembentukan, pola pergerakan KANTIBMAS KALBA Kabupaten Bantaeng, pergerakan, dan dampak pergerakan KANTIBMAS KALBA Kabupaten Bantaeng dari tahun 1999-2014. Hasil penelitian ini menemukan bahwa pembentukan dan pergerakan KANTIBMAS KALBA Kabupaten Bantaeng dilatarbelakangi oleh rasa kekecewaan masyarakat Desa Kaloling, Layoa dan Bajiminasa terhadap aparat kemanan yang tidak efektif dalam mengendalikan para pelaku kejahatan di Kabupaten Bantaeng yang semakin meresahkan dan mengancam ketentraman masyarakat. Selain itu, pergerakan yang dilakukan oleh kelompok KANTIBMAS KALBA Kabupaten Bantaeng terstruktur dengan rapi serta sangat efektif sehingga memberikan dampak yang bisa dirasakan oleh masyarakat dengan mulai terkontrolnya keamanan dan ketertiban masyarakat di Kabupaten Bantaeng. Setiap operasi yang dilakukan menjadi shock teraphy bagi para pelaku kejahatan yang membuat sebanyak 1.062. Pelaku kejahatan di Kabupaten Bantaeng ditahun 1999-2003 menyerahkan diri ke pihak berwajib. Keberhasilan ini menginspirasi daerah lain untuk membentuk pergerakan yang serupa seperti di bentuknya Massa Kabupaten Jeneponto, Massa Kabupaten Takalar, Massa Kabupaten Gowa, Massa Kabupaten Bulukumba, Sinjai, Forbes Bone dan Pinrang. peneliti mendesain penelitian ini bersifat kualitatif deskriptif dengan menggunakan metode penulisan sejarah (historis) yang melalui tahapan-tahapan Heuristik, Kritik, Interpretasi dan Historiografi
\end{abstract}

\section{Kata Kunci: Pergerakan, KALBA Bantaeng}

\begin{abstract}
This paper discusses the Movement of Kaloling, Layoa, Bajiminasa in Bantaeng 1999-2014. This study aims to discuss the background of the formation, movement patterns KANTIBMAS KALBA Bantaeng District, the movement, and the impact of movement KANTIBMAS KALBA Bantaeng District from 1999-2014. the researchers designed this research is qualitative descriptive by using historical (historical) method of writing. Through the stages of Heuristics, Criticism, Interpretation and Historiography The results of this study found that the formation and movement of KANTIBMAS KALBA Bantaeng Regency backed by a sense of disappointment of the villagers Kaloling, Layoa and Bajiminasa against security forces that are not effective in controlling the perpetrators of crime in Bantaeng District that increasingly troubling and threatening ketentraman community. In addition, the movement carried out by the KANTIBMAS KALBA Bantaeng District is stru (Anon., t.thn.)ctured neatly and very effectively so as to provide an impact that can be felt by the community by starting to control the security and public order in Bantaeng Regency. Every operation performed was a shock teraphy for the perpetrators of the crimes that made as many as 1,062. The perpetrators of crime in Bantaeng District in 1999-2003 surrendered themselves to the authorities. This success inspired other regions to form similar movements such as the Massa of Jeneponto, Massa Takalar, Massa Gowa, Bulsaumba, Sinjai, Forbes Bone and Pinrang. The researchers
\end{abstract}


designed this research is qualitative descriptive by using historical (historical) method of writing. Through the stages of Heuristics, Criticism, Interpretation and Historiography

\section{Keyword: Movement, Kalba Bantaeng}

\section{A. Pendahuluan}

Sulawesi Selatan pada tahun 1999 menghadapi persoalan sosial yang cukup serius, tanpa terkecuali Kabupaten Bantaeng yang terletak dibagian selatan sulawesi selatan. Bantaeng salah satu daerah yang cukup berkecamuk, dengan angka kejahatan dalam sehari bisa mencapai 5 (Lima) kasus kejahatan yang meliputi pencurian, pemerkosaan, perjudian, perampokan hingga pembunuhan. Sementara seluruh masyarakat menghadapi kecaman para pelaku kejahatan aparat keamanan sudah merasa kuwalahan akan tingkah laku para pelaku kejahatan.

Sebagai dampak dari ketidak stabilan sosial yang diakibatkan oleh para pelaku kejahatan dan ketidak mampuan aparat keamanan untuk mengendalikan para pelaku kejahatan yang sangat meresahkan masyarakat, maka di "Sulawesi selatan ditahun 1999 ramai dilaksanakan main hakim sendiri oleh masyarakat (Rahardjo, 2009). Kegiatan mai hakim diawali didaerah kabupaten Bantaeng yang berinisiatif untuk mendirikan keamanan berbasis masyarakat dengan jumlah basis massa sekitaran 400 orang melalui sebuah wadah yang dinamakan Kaloling, Layoa dan Bajiminasa (KALBA) Kabupaten Bantaeng (Rahardjo, 2009). Wadah yang awalnya hanya memiliki anggota massa sekitar 400 orang kemudian mengalami perkembangan hingga 4000 massa serta wilayah cakupannya juga semakin meluas, kelompok-kelompok ini menamakan diri mereka sebagai kelompok massa (Hasanuddin, 2003)

KALBA cukup besar di tahun 2000an hingga aksi terakhirnya ditahun 2014. Ibaratnya teori efek domino yang banyak diperkenalkan oleh para ahli strategi internasional untuk menggambarkan hubungan antara suatu ideologi dan pengaruhnya, pergerakan KANTIBMAS KALBA Kabupaten Bantaeng yang berhasil menginspirasi beberapa daerah lain yang ada di Sulawesi Selatan ibaratnya suatu fenomena susun bangun kartu domino, yang apabila salah satu kartu itu jatuh baik secara disengaja atau lemah secara alamiah maka seluruh rangkaian kartu domino tersebut akan jatuh secara berurutan (Aman, 2014). Beberapa daerah yang meniru pergerakan kelompok ini adalah "Massa Jeneponto, Massa Takalar, Massa Goa, Forbes di Bone, Massa Sinjai dan Massa Pinrang (Rahardjo, 2009) yang diawali dari Kabupaten Bantaeng dan bergulir saling mempengaruhi secara teratur.

Selain itu, peneliti juga belajar dari beberapa penelitian terdahulu tentang pergerakan organisasi massa seperti Skripsi oleh Novi Andrianthy ditahun 2009 dari Universitas Sumatera Utara dengan judul "Gerakan Sosial Aktivisme GEMKARABP3KB dan pengaruhnya dalam mewujudkan Kabupaten Batubara (Andrianthy, 2009). Skripsi dengan judul "Tinjauan Syariat Islam Tentang Forum Aksi Peduli KANTIBMAS KALBA dalam Memberantas Kriminalitas di Kabupaten Bantaeng” yang fokus pada pengulasan syariat islam yang terdapat pada pergerakan KANTIBMAS KALBA Kabupaten bantaeng (Saleh, 2000)

Merujuk pada deskriptif diatas, maka peneliti merasa tertarik untuk mengetahui dan melihat suatu sudut nyata perubahan sosial yang terjadi melalui gerakan sosial, khususnya dari gerakan yang dilakukan oleh kelompok KANTIBMAS KALBA Kabupaten Bantaeng. Banyak hal yang ingin lebih dieksplor peneliti untuk bisa mengetahui sejarah pegerakan yang dilakukan oleh kelompok ini termasuk 
efek domino dari pergerakan yang dilakukan.

\section{B. Metode Penelitian}

Penelitian ini adalah penelitian kualitatif deskriptif dengan menggunakan metodologi sejarah, metode ini sering di pergunakan dalam ilmu sejarah dan disiplin ilmu sosial lainya dengan tujuan untuk menemukan suatu hal yang unik dan mampu membantu mengungkapkan peristiwa yang telah terjadi dimasa lampau (Priyadi, 2012) yang meliputi heuristik, kritik, interpretasi dan historiografi.

\section{Heuristik}

Teknik atau cara-cara untuk menemukan sumber dari topik penelitian misalnya arsip, dokumen, sumber lisan dan sumber benda (Primer) serta sumber pelengkap seperti buku, jurnal dan laporan hasil penelitian (dkk, 2008).

Dalam penelitian ini, peneliti mengumpulkan tulisan tentang KALBA dari berbagai bentuk berita, kliping, persuratan, arsip dan berbagai dokumentasi Organisasi yang didapatkan dari pengurus Organisasi, skripsi, beberapa buku yang berhubungan dengan organisasi, beberapa dokumentasi yang didapatkan dari sekretaris organisasi serta wawancara dengan masyarakat dan juga aparat desa yang menyaksikan langsung kejadian tersebut.

\section{Kritik}

Kritik sumber penting dalam menilai keabsahan data (Priyadi, 2012) Pada tahapan ini, data yang telah didapatkan dicocokan satu sama lain termasuk wawancara dengan saksi kejadian dan pengurus oganissi untuk menemukan yang benar. Selain itu, Koran-koran dan beberapa arsip organisasi yang diperoleh juga di perhatikan secra isi dan konten termasuk mengkritik isi dari beberapa skripsi yang di gunakan untuk bahan rujukan.

\section{Interpretasi}

Interpretasi diperlukan agar data yang mati bisa bicara atau mempunyai arti.
Dalam penelitian ini peneliti senantiasa menjaga tingkat obyektifitas ada beberapa cara yang dilakukan diantaranya adalah memperlihatkan tulisan kepada beberapa narasumber dan orang-orang yang dianggap berkompeten termasuk pelaku sejarah serta rutin melakukan konsultasi dengan dosen pembimbing.

\section{Historiografi}

Dalam menyusun interpretasi kedalam sebua cerita, diperlukan kemampuankemampuan tertentu untuk menjaga standar mutu dari cerita tersebut. Penyusunan data dalam penelitian iini disesuaikan dengan data yang didapat selama penelitian di lapangan.

\section{Tinjauan Penelitian}

1. Keadaan Geografis

Kabupaten Bantaeng terletak dibagian selatan Provinsi Sulawesi Selatan dengan jarak kira-kira $120 \mathrm{~km}$ dari Kota Makassar dan terletak pada 05-21'15" LS sampai 05⒊'3" LS dan 119²51'07” BT sampa 12051'07” BT (UNHAS, P2KKN, 2014) Membentang antara Laut Flores dan Gunung Lompo Battang, dengan ketinggian dari permukaan laut 0 sampai ketinggian lebih dari $100 \mathrm{~m}$ dengan panjang pantai $21,5 \mathrm{~km}$. Secara umum luas wilayah Kabupaten Bantaeng adalah 395,83 km2. Pada penelitian ini lokasi penelitian adalah tiga desa di Kabupaten Bantaeng yaitu:

a. Kaloling dengan geografis terletak dibagian tenggara Bantaeng, letak Desa Kaloling berada pada $5^{\circ} 30$ '00"$5^{\circ} 32^{\prime} 30^{\prime \prime}$ Lintang selatan dan diantara $120^{\circ}$ 2'30"-120'5'00'Bujur Timur dengan luas wilayah $1650 \mathrm{Ha}$ (UNHAS, P2KKN, 2014). Desa Kaloling pada bagian utaranya bebatasan dengan kecamatan Tompobulu, barat desa Tanah Loe, timur desa Bajiminasa, tenggara Layoa dan pada bagian selatan berbatasan dengan kecamatan Pakjukukang.

b. Kondisi geografis Desa Layoa berada di dataran rendah dengan luas wilayah 9,8 km2 . Jarak dari desa ke kecamatan sekitar $17 \mathrm{~km}$ dan jarak dari desa ke ibu kota kabupaten sekitar $26 \mathrm{~km}$ 
dengan batas wilayah bagian utara Bajiminasa, sebelah timur kabupaten Bulukumba, sebelah selatan desa Baruga dan sebelah barat desa Papan Loe (UNHAS, P2KKN, 2014)

c. Kondisi geografis Desa Bajiminasa pada bagian utaranya berbatasan dengan Kecamatan Tompobulu,

\section{Keadaan Demografis}

Rata-rata kepadatan penduduk Kabupaten Bantaeng selama kurun waktu 5 tahun (2007-2011) yang diambil dimasing-masing kecamatan adalah 441 jiwa/km2 termasuk Kecamatan Gantarangkeke sebagai Kecamatan administratif Desa Kaloling, Layoa dan Bajiminasa yang menjadi pelopor pergerakan massa KALBA (UNHAS, P2KKN, 2014).

\section{Keadaan Sosial Budaya}

Dilihat dari kesejahteraan masyarakat di Kab. Bantaeng, keluarga yang masih perlu menjadi perhatian yaitu keluarga pra sejahtera dimana pada tahun 2011 dengan jumlah yang cukup signifikan mencapai 15.329 KK dari 47.861 KK atau sekitar (UNHAS, P2KKN, 2014)

\section{Pembahasan}

\section{Pembentukan kantibmas Kalba}

\section{Bantaeng}

KANTIBMAS KALBA Kabupaten Bantaeng merupakan sebuah wujud nyata dari PAM SWAKARSA oleh kelompok masyarakat tiga desa yakni Kaloling, Layoa dan Bajiminasa yang membantu aparat kepolisian dalam menciptakan rasa aman dan nyaman dikalangan masyarakat Kabupaten Bantaeng. pembentukan KANTIBMAS KALBA Kabupaten Bantaeng di pengaruhi oleh permasalahan Nasional maupun lokal yang terjadi ditahun 1999. Beberpa faktor yang mempengaruhinya adalah

\section{a. Dampak Krisis Monoter.}

Krisis monoter ditahun 1997/1998, menjadikan Negara Indonesia sebagai salah satu Negara yang terpuruk dibidang ekonomi yang berujung pada meningkatnya kejahatan hingga 5 kasus kejahatan dalam sehari, dari yang sebelumnya hanya sekitar 1 kasus pencurian dalam seminggu (Ajil, 1999)

\section{b. Kejahatan di Kabupaten Bantaeng}

Ditahun 1999 pasca Pemilu hampir seluruh wilayah Bantaeng di Kuasai oleh orang tidak bertanggung jawab, Tingginya jumlah kejahatan masa itu di tunjukan dengan jumlah masyarakat yang melanggar lebih banyak dibandingkan yang taat aturan (wawancara dengan Natsir, 18 Februari 2018) "sebagai Sumber kehidupan masyarakat petani di desa adalah hasil kebun mereka. Tetapi kasihan, jagung, coklat, dan jambu mente yang mereka tanam kadang tidak dinikmati hasilnya kerena lebih dulu dipanen oleh pencuri (Ahr/mu., 1999) Ketidak puasan warga terhadap kinerja aparat keamanan dan dominasi para pelaku kejahatan di tahun 1999 membuat masyarakat berinisiasi mendirikan kelompok keamanan masyarakat berbasis masyarakat.

Pada tanggal 09 Juli 1999 bertepatan dengan 25 Rabiul awal 1420 hijriah dibentuklah KANTIBMAS KALBA Bantaeng yang sekretariatnya di Jl.Mallarangan No 2 Kaloling. Pembenukan KALBA Kabupaten Bantaeng, Manggassingi ditunjuk sebagai pendiri, H. Kr. Jumatta dari Desa Layoa sebagai pembina, Drs Hasanuddin dari Desa Kaloling sebagai ketua, Sekretaris dan Humas Oleh Drs. Muh. Natsir MS., Husain HL, SE Sebagai Bendahara serta beberapa dewan pimpinan cabang lainnya yang terdiri atas 7 penanggung jawab secara interen dan exteren dari 9 kelompok yang ada di 3 desa .

Setelah pembentukan organisasi oleh tujuh penanggungjawab Interen dan Exteren maka tahapan selanjutnya adalah pembentukan 9 kelompok pendukung massa (KPM) Massa di tiga desa, Kesembilan kelompok ini merupakan wadah untuk menghimpun 9 kelompok besar di distrik desa masing-masing yang 
langsung di komandoi oleh ketua masingmasing dan melakukan koordinasi dengan pimpinan KALBA Bantaeng dengan penamaan sekretariat mereka yakni Sekretariat 379 mallarangeng. Sandi ini di berlakukan untuk mengenal sekaligus sebagai penanda bahwa mereka berdiri atas 3 desa yaitu Kaloling, Layoa dan Bajiminasa yang di tanggungjawabi oleh 7 orang dan berdiri dengan sembilan kelompok dengan sekret berada di Jl Mallarangeng Kabupaten Bantaeng.

Pola pergerakan yang diberlakukan KALBA melalui tahapan seperti memperluas jaringan dengan membentuk Forum ditiap Kecamatan, Mengajak bekerjasama untuk membasmi kejahatan, Mengingatkan pelaku kejahatan untuk menyerahkan diri kepihak yang berwajib serta Dieksekusi pelaku kejahatan yang tidak mau menyerahkan diri. Namun, apara pelaku ini tidak semuanya di eksekusi oleh KALBA karena para penjahat dibedakan dalam tiga kelompok yakni Hijau, Kuning dan Merah (BB, 1999).

Warna hijau adalah warna yang akan diberikan untuk menandai para pelaku kejahatan yang masih berada di tingkatan pemula, Warna kuning diberikan untuk pelaku kejahatan kategori menengah namun kelasnya masih kecil-kecilan seperti pencuri ayam, peminum, perjudian dan persinahan termasuk Bandar Kupon Putih (Togel) dengan perempuan esek-esek dan penjahat tidak mengindahkan peringatan pada tahapan hijau Pada tingkatan ini para pelaku kejahatan sudah harus berhati-hati dengan tindakannya.

Warna Merah yang diberikan untuk para pelaku kejahatan menunjukan tatanan kelas kakap yang sudah sering melakukan pencurian berupa ternak kuda dan sapi dalam skala besar dan masuk dalam kategori Residifis dan tidak mengindahkan peringatan pada garis hijau dan kuning, Hukuman untuk pelaku kejahatan yang seperti ini akan dijemput paksa oleh kelompok KANTIBMAS KALBA
Bantaeng untuk diserahkan ke pihak berwajib atau di eksekusi oleh masyarakat hingga tewas sehingga banyak tersangka yang ketika mengetahui dirinya masuk dalam daftar garis merah lari keluar negeri dan tidak ingin kembali lagi.

KANTIBMAS KALBA kab. Bantaeng dalam melakukan operasinya tidak pernah mendapatkan bantuan dana sedikitpun dari pemerintah atau instansi manapun, melainkan keikhlasan masyarakat. sedang untuk konsumsi, massa mendapatkan makanan dari pemberian warga. Namun banyak massa yang terkadang merasa takut mengonsumsi makanan yang di berikan warga sehingga terkadang makanan yang disajikan harus terlebih dahulu dicicipi warga penyaji didepan massa sebelum dinikmati bersama-sama oleh massa.

\section{Pergerakan KANTIBMAS KALBA a. KALBA 1999}

Setelah terbentuk, kelompok KANTIBMAS KALBA Kab. Bantaeng menyambangi salah seorang tersangka yang berinisial $\mathbf{M}$ bin $\mathbf{M}$ di perkampungan dekat perbatasan layoa dan bajiminasa dengan jumlah massa sekitaran 400 orang- 4000 orang. Proses eksekusi yang dilakukan ditahun 1999 meliputi

1) 12 Juli 1999 menewaskan $\mathbf{M}$ bin $\mathbf{M}$ (Ahr/mu, 1999)

2) Operasi 14 Juli 1999 menewaskan K Bin M (Halwin, 13 Januari 2018)

3) Pembentukan Kelompok Pendukung Kelompok (KPK) (Hasanuddin, 2003).

4) Perjanjian Rambu-rambu Operasi Perjanjian ini disepakati oleh Muspida bersama kelompok KANTIBMAS pada tanggal 20 Juli 1999 untuk mengatur pergerakan organisasi.

5) Operasi 25 Juli 1999 menewaskan S dengan kasus pembunuhan terhadap istrinya sendiri (KZ, 1999).

6) Operasi 28 Juli 1999 menewaskan $\mathrm{S}$ di Daerah Jampea secara tragis dengan leher hampir putus di tebas oleh Massa

7) Tragedi Lubang Buaya.

Eksekusi A, istilah ini diberikan karena proses eksekusi A yang miri 
dengan pembunuhan 7 Jenderal G30 S (Halwin, 13 Januari 2018)

8) Operasi 8 September 1999 Menewaskan $\mathbf{M}$ dengan kasus pencurian hewan ternak $(\mathrm{Ahr} / \mathrm{mu}$, 1999)

9) Operasi $12 \quad$ September 1999 menewaskan $\mathrm{S}$ di daerah Jampea Desa kaloling oleh kelompok KANTIBMAS KALBA Kab. Bantaeng.

10) Surat 21 September. pada tanggal 21 September 1999 dengan nomor 031/FAPKKM/KLB/IX/1999 dan ditanda tangani oleh pembinanya $\mathrm{H}$. $\mathrm{Kr}$. Jumatta (PR, 2000)

11) November 1999. kelompok KALBA turut menyuarakan anti narkoba di Kabupaten Bantaeng. gebrakan ini merupakan yang pertama di Indonesia (KZ, 1999)

b. Pergerakan KALBA tahun 2000-an

1) Operasi 27 Januari 2000 Tanggal 27 Januari 2000 KANTIBMAS KALBA kembali menyambangi kantor PDAM Kab. (Ahr/mu., 2000)

2) Seminar Sehari di tahun 2000 melaksanakan seminar sehari KANTIBMAS yang dihadiri oleh 7 pembicara termasuk Guru besar Fakultas Hukum Universitas Hasanuddin Prof. Dr. Ahmad Ali, SH, MH. dengan mengusung tema Membedah Eksistensi Komunitas Massa dalam Perspektif Hukum (Hasanuddin, 2003)

3) Pembentukan HPKB. Hari rabu tanggal 25 Oktober tahun 2000 atau bertepatan dengan tanggal 27 Rajab 1421 Hijriah dibentuk pembentukan Himpunan Pencinta Kantibmas Bantaeng yang lalu disingkat dengan nama HPKB Kabupaten Bantaeng (Hasanuddin, 2003)

4) KALBA Tahun 2008. Berdasarkan Surat Keputusan pengangkatan panitia pelaksana nomor 021/FAP-KKM /KLB-KPTS/IV/2008, maka kegiatan
Sepak Bola KALBA CUP dilaksanakan untuk yang pertma kalinya di lapangan MOTIVASI Moti Desa Bajiminasa Kabupaten Bantaeng sebagai simbolik kesatuan masyarakat, KANTIBMAS KALBA Bantaeng

5) KALBA Tahun 2010 dipanggil dalam persidangan sebagai saksi terhadap adanya oknum TNI yang terlibat dalam kelompok pencuri di Kabupaten Bantaeng (wawancara dengan Natsir, 18 Februari 2018)

6) Massa Tahun 201 dilatar belakangi oleh banyaknya kasus pencurian anak di bawah umur sejak peng hujung tahun 2010.

7) Massa Tahun 2014 beroperasi pada tanggal 3 Agustus 2014, dalam operasi tersebut kelompok massa menyisir daerah Bateballa dan Panrang Putang serta beberapa daerah lainnya

\section{Dampak Pergerakan Kantibmas Kalba Bantaeng \\ a. Bidang Keamanan}

Eksistensi kelompok KALBA ini hampir semua anggota masyarakat di daerah ini sangat memujinya. Alasannya, dengan gerakan KALBA ini membuahkan bukti selama enam bulan beroperasi Bantaeng aman dari gangguan penjahat. Dengan begitu mayoritas masyarakat Bantaeng berterima kasih kepada massa KALBA (Ahr/mu., 1999). Penggalan berita diatas merupakan gambaran keamana di Kabupaten Bantaeng setelah berdiri, beroperasinya kelompok KANTIBMAS KALBA Kab. Bantaeng. 1) Tugu Tragedi Bale Balang

Penyerangan Bale Balang adalah salah satu operasi terbesar yang terjadi dalam sejarah KANTIBMAS KALBA Kabupaten Bantaeng, walaupun sebenarnya bale baling sudah termasuk wilayah administrasi Kabupaten Jeneponto.

Kesiapan perampok di daerah Bale Balang untuk menjamu serangan dari para kelompok Massa memang terasa dengan 
pertarungan mereka yang berlangsung hingga semalaman suntuk. Ada banyak korban jiwa dalam kejadian tersebut yang berasal dari kedua belah pihak tanpa terkecuali beberapa pimpinan mereka. Untuk mengenang tragedi ini, maka di Bale Balang telah dibuat tuguh massa yang menyerupai tuguh korban 40.000 jiwa yang berukuran sekitar $5 \times 2$ meter.

\section{b. Sebagai Shock Teraphy}

Para penjahat di Kabupaten Bantaeng akhirnya jadi keder. Tidak sedikit yang menyingkir, apalagi yang mengetahui namanya masuk dalam daftar pencarian orang. Maka ramai-ramailah mereka meninggalkan kampong halamannya, ada yang keluar daerah atau keluar negeri. Kemalaysia misalnya, semua itu mereka lakukan untuk bisa menyelamatkan diri (PR, 2000). Selain banyaknya jumlah buronan yang merasa takut dan lari keluar negeri, ada juga para pelaku penjahat lainnya yang masih ingin berdomisili di Kabupaten Bantaeng menyerahkan diri kepihak yang berwajib untuk mendapatkan perlindungan dan dibina

\section{c. Ekonomi}

Keberadaan para kelompok pencuri di Kabupaten Bantaeng memang sangat mer ekonomi masyarakat Kabupaten Bantaeng karena langsung mengarah pada sektor utama pendapatan warga yaitu bertani dan berternak. Setelah sebanyak 1062 pelaku kejahatan di Kabupaten Bantaeng menyerahkan diri kepihak yang berwajib maka sudah dirasakan dampaknya oleh masyarakat termasuk di bidang Ekonomi, masyarakat yang ada di Kecamatan Tompobulu tidak lagi kehilangan hasil bumi berupa Cengkeh, Coklat dan Kopi serta masyarakat Kecamatan Gantarangkeke tidak lagi kehilangan hewan ternak, jagung dan jambu mete.

\section{d. Efek Domino}

Keberanian masyarakat tiga desa di Kabupaten Bantaeng membentuk kelompok pergerakan untuk melawan ketakutan terhadap pelaku kejahatan di
Bantaeng berdampak terhadap Kabupaten lain. Pengaruh ini merupakan efek teori domino yang menggambarkan saling keterkaitan atau hubungan suatu ideologi dan pengaruhnya, suatu agama, suatu Budaya sekuler, kebijakan politik dan moneter, maupun saling berhubungan antara Negara-negara dengan mengambil fenomena yang terjadi (Aman, 2014).

Dalam permainan domino, jika salah satu kartu kunci diambil oleh penyusun maka kartu penyusun yang lain akan ikut dan apabila sang penyusun mulai memainkan domina maka kartu yang lain akan ikut secara berurutan. KALBA Bantaeng dalam kasus ini diibaratkan sebagai kartu kunci yang memulai pergerakan perlawanan terhadap pelaku kejahatan yang meresahkan masyarakat dan berhasil menarik beberapa daerah untuk membentuk kelompok yang serupa.

Keberhasilan KALBA dalam mengawal keaman dan ketertiban masyarakat Bantaeng ternyata berhasil mengubah pola pikir, cara pandang dan cara bertindak masyarakat untuk melawan pelaku kejahatan yang cukup meresahkan.

Proses perubahan pola pikir dan tindakan oleh masyarakat bantaeng diikuti oleh Masyarakat di berbagai kabupaten lain yang merupakan suatu gerakan revolusi untuk menjatuhkan kekuatan dan kekuasaan para pelaku kejahatan di Sulawesi Selatan tahun 1999.

\section{1) Pembentukan Massa Jeneponto}

Letak geografis Kabupaten Jeneponto yang berbatasan langsung dengan Kabupaten Bantaeng menjadikan Kabupaten Jeneponto mendapatkan pengaruh dari Bantaeng. Selain itu, Jeneponto juga merasakan keresahan atas tingkah pelaku kejahatan sehingga melihat dampak dari kegiatan KALBA Bantaeng, maka masyarakat jeneponto akhirnya tertarik membuat pergerakan yang sama, pergerakan ini dimulai di daerah perbatasan Bantaeng- Jeneponto yaitu daerah Rumbia dan Bale Balang 
(wawancara dengan Natsir, 18 Februari 2018).

\section{2) Pembentukan Massa Kabupaten} Takalar

Setelah daerah Jeneponto mendapatkan pengaruh dari KALBA Bantaeng dan juga berhasil menumpas pelaku Kejahatan di daerahnya, Takalar yang berbatasan langsung dengan Jeneponto juga mengikut mendirikan kelompok Massa untuk mengendalikan pelaku kejahatan di Takalar.

\section{3) Massa Gowa}

Kemunculan Massa di Kabupaten Gowa juga merupakan efek domino dari pergerakan Massa di Kabupaten takalar pada saat itu yang telah menyentuh kehidupan dari masyarakat Kabupaten Gowa.

\section{4) Massa Bulukumba}

Pada bagian selatan bulukumba yang berbatasan dengan Bantaeng ditahun 1999 juga banyak kelompok pelaku kejahatan (Halwin, 13 Januari 2018) Operasi yang dilakukan KALBA ternyata menyentuh daerah ini dan menjadikan daerah ini aman, sehingga masyarakat Bulukumba juga ikut membentuk kelompok massa walau tidak secara resmi.

\section{5) Massa Sinjai, Bone dan Pinrang}

Ditahun 2000, kapolres Bantaeng dimutasi ke Kabupaten Bone. Masyarakat Bantaeng pada saat itu yang tergabung dalam kelompok massa mengantar kapolres Bantaeng ke Kabupaten Bone dan Sempat mampir slat berjamaah di salah satu masjid di kabupaten Sinjai, Selepas salat berjamaah, menurut Rahim banyak warga sekitar yang menghampiri dan bertanya tentang kelompok ini. Setelah di jelaskan tentang kelompok KALBA masyarakat Sinjai merasa tertarik dan juga membentuk kelompok yang sama. (wawancara dengan Natsir, 18 Februari 2018).

Setelah bertugas selama beberapa bulan di Kabupaten Bone, Ex Kapolres Bantaeng pada saat itu melihat bahwa Kabupaten Bone juga cukupdiresahkan dengan keberadaan pelaku kejahatan di Bone, sehingga muncul inisiatif untuk kembali membentuk Ormas Bone seperti KALBA Bantaeng dan dinamai FORBES (KZ., 1999). Kehadiran FORBES di Bone ini menandai awal pembentukan kelompok massa di kawasan bugis termasuk Massa Kabupaten Pinrang.

\section{E. Kesimpulan}

Pergerakan yang dilakukan oleh kelompok KANTIBMAS KALBA Kabupaten Bantaeng ada sebagai sebuah akibat keresahan atas aktifitas para pelaku kejahatan yang ada di Kabupaten Bantaeng pada tahun 1999. Pergerakan kelompok KANTIBMAS KALBA Kabupaten Bantaeng di mulai sejak dibentuknya tanggal 09 Juli 1999 dan berakhir ditahun 2014.

Pergerakan yang dilakukan dengan menangkapi dan memproses termasuk mengeksekusi para pelaku kejahatan di Kabupaten Bantaeng yang mencoba melakukan perlawanan saat ditangkap, tertata secara rapi dan mampu memberikan efek jera serta shock kepada seluruh lapisan pelaku kejahatan yang ada pada masa itu yang menyebabkan ditahun 2003 tercatat sudah sebanyak 1062 pelaku kejahatan dari berbagai kalangan di Kabupaten Bantaeng menyerahkan diri kepihak yang berwajib untuk diproses. Kegiatan ini juga menjadi kunci pembuka kegiatan massa di Sulawesi Selatan sekaligus memberikan efek domino bagi beberapa daerah lain sperti Jeneponto, Takalar, Gowa, Makassar, Sinjai, Bone dan Pinrang

\section{DAFTAR PUSTAKA}

P2KKN Universitas Hasanuddin, P.rofil Desa Kaloling. Desa Sejahtera Mandiri Berbasis Wisata Pertanian \& Ekonomi Kreatif.

Rahardjo, Satjipto. 2009. Hukum dan Perilaku: Hidup Baik adalah 
Sumber Hukum yang Baik. Jakarta: Buku Kompas.

Saleh Madjid, Muhammad dan Abdul Rahman Hamid. 2008. Pengantar ilmu sejarah. Makassar: Rayhan Intermedia.

Sugeng Priyadi. 2012. Metode Penelitian Pendidikan Sejarah. Yogyakarta: Ombak.

Hasanuddin. 2003. Problematika dan Undang-undang (Study Fenomena Gerakan Massa dalam Konstelasi Hukum Indonesia). Kegiatan ADVANCED TRAINING Badan Eksekutif Mahasiswa Universitas Negeri Makassar (BEM UNM). Gedung KNPI Sudiang Makassar.

Natsir. 2000. Aktualisasi dan Peran Masyarakat Kaloling, Layoa, Bajiminasa (KALBA). Seminar Sehari. Gedung Olahraga Kabupaten Bantaeng.

Ahr/mu. 8 September 1999. "Satu Lagi Pencuri dibunuh di Bantaeng:. Koran Aneka Berita.

Ahr/mu. 21 Januari 2000. "Massa Bersenjata Tajam Datangi Dirut PDAM Bantaeng”. Koran Opini.

Ajil. 1999. "Lalu Parangpun Bicara". Koran Amanat Rakyat Edisi No 10 tahun I/25 AGT-10 SEPT.

KZ. 20 Juli 1999. "Penjahat Tewas dibantai Massa”. Koran Pedoman Rakyat Edisi tahun ke 53 No 13319 Juli Hal. 11.

Ahr/mu. 20 Juli 1999. "Masyarakat Bantaeng Berterima Kasih Pada
Forum KALBA”. Koran Pedoman Rakyat Edisi tahun ke 53 No 20926 Juli.

PR. 21 Januari 2000. "Forum KALBA: Antara Pelanggaran Hukum dan HAM”. Koran Pedoman Rakyat Edisi Jumat.

KZ. 20 Juli 1999. "Kapolres Dukung Gerakan Forum KALBA". Koran Pedoman Rakyat Edisi tahun ke 53 No 134 26Juli Hal. 11.

KZ. 27 Juli 1999. "Syarifuddin Tewas dibantai Massa Setelah Sembelih Isterinya”. Koran Bina Baru hal.11.

25 Agustus 1999. "Hijau, Kuning dan Merah”. Koran Bina Baru.

Noesa, Mahaji. 2011. Pam Swakarsa Beraksi Perampok Ketakutan. Makassar:Kompasiana.com.15 Juni 2011 09:57.

Hatta Wahab. 16 Februari 2000. Pelaku pencurian dan Bandar Judi akp Sulit Bernafas Lega di Bantaeng. Koran Perintis Edisi 16-29 Februari 200.

Irenewati Terry dan Aman. 2014. Dampak Teori Domino di Negara-negara Afrika Utara. Skripsi Universitas Negeri Yogyakarta. 